Canadian Journal of Forest research

2000, 30:1847-1857

Doi: $10.1139 / \times 00-107$

\title{
Impact of liming on the abundance and vigor of Armillaria rhizomorphs in Allegheny hardwoods stands
}

\author{
B. Marçais ${ }^{1}$ and P. M. Wargo ${ }^{2}$ \\ ${ }^{1}$ Laboratoire de Pathologie Forestière, INRA Nancy, F54280 Champenoux, France \\ Tel. 03833940 53, Email marcais@nancy.inra.fr \\ ${ }^{2}$ USDA, Forest Service, 51 Mill Pond, Hamden, CT 06514, USA.
}

\section{Summary}

Abundance of rhizomorphs of Armillaria was characterized in 1995-96 in 32 plots located in Acer saccharum (sugar maple) stands in the Susquehannock State Forest (Pennsylvania, USA). All of the plots were thinned and half of the plots were limed in 1985 when the plots were established. Frequency and abundance of Armillaria rhizomorphs in soil samples, on dead wood food bases, (stumps, snags, fallen logs) and on the root collar of living sugar maples were determined in each plot. Rhizomorph vigor was evaluated by measuring their ability to colonize fresh striped maple, Acer pennsylvanicum, stem sections in the soil, or potato tubers in the laboratory. Isolates of Armillaria were obtained from rhizomorphs in the soil samples and species were determined by somatic incompatibility tests. Armillaria calvescens was the major species present, representing about 66 percent of the isolates. Armillaria gemina and A. mellea were also identified in the plots. Frequency of rhizomorphs in the soil, on food bases, abundance of rhizomorphs on root collars, as well as the proportion of rhizomorphs per plot that regenerated and/or colonized fresh substrates were all correlated. However, abundance of ectotrophic rhizomorphs on the root collar was only weakly correlated with the other components of rhizomorph abundance and vigor. Frequency of the rhizomorphs as well as their ability to colonize fresh substrates were greater in plots either limed or with a high proportion of the basal area in sugar maple prior to thinning. By contrast, abundance of ectotrophic rhizomorphs on root collars was not affected by these factors.

\section{Introduction}

Since the mid-1980's, overstory trees in mature sugar maple stands (Acer saccharum Marsh.) have been dying and declining across the Allegheny Plateau in northern Pennsylvania, resulting in reduced stocking (Kolb and McCormick, 1993; McWilliams et al., 1996). Sugar maple decline (sensu Manion 1991) has been 
associated with stress from insect damage and drought events in the mid-1960's and early 1970's, from repeated defoliation by pear thrips (Taeniothrips inconsequens Uzel) in the early 1980's, and from drought in 1988 (Kolb and McCormick 1993). Other evidence suggests that soil nutrient status may also play some role in this decline (Long et al. 1997). Recent observations also indicated that Armillaria root disease is widespread in these forests and the fungus is causing mortality in declining sugar maple stands in the Allegheny National Forest and surrounding State Forests (P.M. Wargo, USDA Forest Service, unpublished results).

Armillaria species present in hardwoods in the northeast United States are mainly A. calvescens Bérubé and Dessureault and A. gallica Marxmuller \& Romagnesi (Blodgett and Worral, 1992a). A. calvescens is found primarily on sugar maple while A. gallica is found mainly on oak (Blodgett and Worrall 1992b). Both of these species are mainly secondary root pathogens unable to attack vigorous trees, but able to colonize and kill trees weakened by defoliation by insects, drought, or poor sites conditions such soil saturation or soil compaction (Wargo, 1980; Wargo and Harrington, 1991). The stressed trees are colonized from rhizomorphs present on the bark surface of roots or from quiescent lesions reactivated by the stress (Wargo, 1977; Wargo, 1984). Rhizomorphs of Armillaria are more abundant in the soil in the vicinity of food bases such as recently colonized stumps, logs or dead trees (Pronos and Patton, 1977, Twery et al, 1990). Trees in the vicinity of food bases could be exposed to a greater Armillaria inoculum, and thus could be more vulnerable to infection in the event of stress. In studies of the impact of artificial defoliation, stressed sugar maples that died were closer to stumps than those that survived (Houston and Kuntz, 1964). So, the number of Armillaria food bases, the abundance of rhizomorphs in the soil and on the root collar, could be important factors determining the severity of mortality in stands of stressed sugar maples.

Little is known about the influence of soil $\mathrm{pH}$ and base saturation on the incidence of Armillaria. In a study of forests in New York state, A. gallica was found on sites with a higher $\mathrm{pH}$ than the others Armillaria species (mean soil pH of 4.6, Blodgett and Worrall $1992 b)$. In work where the growth of $A$. gallica rhizomorphs from colonized wood pieces were compared in soil with pHs of $4-4.4$ or $7-7.7$, rhizomorph growth was either enhanced or not affected in the alkaline soil (Morrison, 1974; Rishbeth, 1985; Guillaumin, 1986). No consistent trend can be seen from those 3 studies concerning the growth of $A$. mellea and $A$. ostoyae rhizomorphs from colonized wood pieces in the same soils. Rishbeth (1982) also observed killing of conifers primarily on acidic soils by A. ostoyae (Romagnesi) Herink, whereas A. mellea (Vahl: Fr) Kummer killed trees on alkaline soils. However, relation between $\mathrm{pH}$ and disease might reflect effects of soil $\mathrm{pH}$ on host rather than on the fungus (Redfern and Filip 1991).

In an attempt to improve tree vigor, flowering, and seed production in declining sugar maples in stands in western Pennsylvania USA, a lime treatment experiment was established on low pH sites (Auchmoody 1985). A recent assessment of this experiment indicates that liming significantly increased diameter growth, improved crown vigor of overstory mature sugar maples, and increased their survival compared to unlimed plots (Long et al. 1997). The objectives of this study were to determine the effects of this lime 
fertilization on the abundance of rhizomorphs in the soil and on the root collars of sugar maple trees and on their ability to colonize substrates, to determine what species of Armillaria were present in these treated blocks, and to determine if reduced mortality on the limed plots was related to inoculum potential of Armillaria.

\section{Material and Methods}

\section{Study plots}

The study plots were established in 1985 by the US Forest Service and Pennsylvania Bureau of Forestry to test the influence of 4 chemical treatments (application of lime, herbicide, lime + herbicide, and control) and 2 fencing treatments (fenced and unfenced - deer control) on flowering and regeneration of sugar maple in four separate blocks (Auchmoody 1985). The four blocks with eight 0.2 ha treatment plots in each are located in the Susquehannock State Forest, in western Pennsylvania on the unglaciated part of the Allegheny plateau (Potter county). Two blocks were located in each of two areas in this forest about 10 mi apart, Black Diamond (Blocks 1 and 2) and Cherry Springs (Blocks 3 and 4). The design of the experiment is a split plot, the 4 chemical treatments being randomized within the fencing treatments. Lime was applied in autumn 1985 when the soil was dry using tractors equipped with conventional spreader. It consist in a single application of commercial pulverized dolomitic limestone $(\mathrm{Ca}=21 \%, \mathrm{Mg}=12 \%, \mathrm{CaO}$ equivalent $=58.8 \%)$ at the rate of $22.4 \mathrm{Mg} \mathrm{ha}^{-1}$. In 1993 , The soil pH in the top $5 \mathrm{~cm}$ was of 6.5 in plot limed and 4.1 in plot unlimed (Long et al, 1997). The herbicide application was glyphosate, applied at $2.2 \mathrm{~kg}^{\text {a.i. ha }} \mathrm{h}^{-1}$ in 1985 . During the winter 1985-86, all plots were thinned to about $50 \%$ relative density. Characteristics of the plots are summarized in Table 1 and are described in more detail in Long et al (1997) as well as the influence of liming on tree growth and crown appearance.

Table 1. Characteristics of the plots in 1985

\begin{tabular}{lcccc}
\hline & Block 1 & Block 2 & Block 3 & Block 4 \\
\hline Soil type $^{\text {a }}$ & $\begin{array}{c}\text { Clymer, } \\
\text { Cookport, } \\
\text { Leetonia }\end{array}$ & $\begin{array}{c}\text { Clymer, } \\
\text { Cookport }\end{array}$ & $\begin{array}{c}\text { Wellsboro, } \\
\text { Wharton }\end{array}$ & $\begin{array}{c}\text { Leetonia, } \\
\text { Wellsboro, } \\
\text { Wharton }\end{array}$ \\
Mean pH (range) & $3.9(3.5-4.3)$ & $3.9(3.6-4.1)$ & $4.0(3.9-4.1)$ & $4.0(3.5-4.1)$ \\
\% basal area pre-thinning in: & & & & \\
Sugar maple & 25 & 28 & 67 & 31 \\
Beech & 26 & 38 & 6 & 11 \\
Black cherry & 42 & 16 & 34.2 & 23 \\
DBH of the sugar maples $(\mathrm{cm})$ & 34.6 & 26.2 & & 23.0 \\
\hline
\end{tabular}

Note. Data from Long et al, 1997

${ }^{a}$ Cookport: Cookport channery loam, Aquic Fragiudult. Clymer: Clymer channery loam, Typic Hapludult. Leetonia: Leetonia channery loam, Entic Haplorthod. Wellsboro: Wellsboro channery silt loam, Typic Fragiochrept. Wharton: Wharton channery silt loam, Aquic Hapludult. 
Marçais et Wargo, 4

\section{Abundance of rhizomorphs in soil, on food bases, and on sugar maple root collars}

Abundance of rhizomorphs in the soil in November 1995 was determined using a technique developed by Wargo et al. (1987). Soil blocks were sampled at each of 9 points of a 11.3 by $11.3 \mathrm{~m}$ grid within each of the 320.2 ha plots (total of 288 soil samples). Blocks, $15 \times 15 \mathrm{~cm}$ and about $10 \mathrm{~cm}$ deep, were cut with a soil knife inside a wooden template, removed with trowels, placed in plastic bags, and transported to the laboratory where they were stored at $5^{\circ} \mathrm{C}$ until processed. The distance of each sampling point to the nearest visible food base colonized by Armillaria (stump, snag, or fallen log more than $15 \mathrm{~cm}$ diameter) were measured. Whether or not a food base was colonized was assessed by digging at the base of the stump or snag or where the log was in contact with the soil and determining if rhizomorphs were firmly attached to it or if there were mycelial fans or pockets of decay typical of Armillaria in the wood.

Frequency of food bases colonization was determined in each plot. Fifteen stumps, snags or fallen logs more than $15 \mathrm{~cm}$ diameter and closest to selected sampling points were evaluated. Care was taken that the same food base was not selected for 2 adjacent grid points. Nine of the grid points were those at which soil blocks were sampled for studying abundance of rhizomorphs in soil, and six were at points halfway between the center and two end grid points. Whether or not a food base was colonized was assessed as previously described. The food base species and type (stump, log or snag) were recorded whenever possible.

Abundance of rhizomorphs on the bark surface of the root collar of living sugar maples was estimated in all plots in 1996 as another measure of inoculum abundance within plots. The root collar of five randomly selected sugar maple trees per plot was partially excavated to a distance of about $15-20 \mathrm{~cm}$ from root soil line into mineral soil. The abundance of ectotrophic rhizomorphs on the bark surface was estimated as absent (1), scarce to light (2), moderate (3), or heavy (4) by visually comparing the density of rhizomorphs on the root collar with standard photographs. Root collars were divided in N-E, S-E, S-W, and N-W quadrants. Each quadrant was visually scored as above and an overall rating for each tree was determined as the average.

\section{Measuring abundance and testing the vigor of rhizomorphs from soil samples}

Each soil sample was dissected in the laboratory and rhizomorph segments were separated from the soil and roots and their length was measured. Ability of the rhizomorphs present in the soil blocks to regenerate in laboratory conditions was studied. For all soil samples with rhizomorphs, 1-3 sections of about $50 \mathrm{mg}$ fresh weight (total) were removed from randomly selected undamaged (except at cut ends) rhizomorphs (no more than one per rhizomorph segment). The minimal length of the sections sampled was $10 \mathrm{~mm}$. The rhizomorph sections were gently washed in dionized water, and their fresh weight and length were recorded. They were then attached to a potato tuber (see Gregory 1984) with plastic twisties. Inoculated tubers were wrapped in sterilized moist paper toweling and placed inside plastic bags (up to 3 per bag for one 
soil sample). Tubers from each plot were then placed inside black garbage bags in a darkened growth chamber. After an incubation of 35 days at about $22^{\circ} \mathrm{C}$, the tubers were unwrapped and the presence and length of new rhizomorphs produced and the presence and extent of lesions in the tubers were recorded.

We also studied the ability of Armillaria to colonize freshly cut striped maple (Acer pennsylvanicum L.) stem sections buried in the soil in all the plots. The grid previously established for sampling the soil blocks in the initial abundance assessment in autum 1995 was used. Two to three maple stem sections, $15 \mathrm{~cm}$ long and 2-3 cm diameter, were placed in the soil in June 1996 within $1 \mathrm{~m}$ of each of the soil sample sites that yielded rhizomorphs. Forest floor was gently lifted and intact rhizomorphs in the soil were located and attached to maple sections with plastic twisties (7-18 rhizomorphs per plot challenged by a maple sections). The maple sections rested in the mineral soil and were covered with the forest floor. After 60 days, the maple sections were relocated and the initial rhizomorph was cut from the network and all the new rhizomorphs formed on or around the section were sampled. The section was removed and returned to the laboratory where they were stored at $5^{\circ} \mathrm{C}$ until processed. In the laboratory, presence of new rhizomorphs that had formed on each section and presence of Armillaria mycelial fans in the cambial area of the maple sections was recorded.

\section{Rhizomorph production in soils from standard inocula}

Rhizomorph production from artificially inoculated sugar maple stem sections was measured in situ in the soil. Two Armillaria isolates from the plots were used; one identified as an $A$. mellea isolate, and the other as an $A$. calvescens isolate. They were established on autoclaved (30 min. 15 psi) sugar maple stem sections $(6 \mathrm{~cm}$ length and about $2 \mathrm{~cm}$ diameter) and were incubated for 120 days prior to their use in the field to ensure establishment of decay in the colonized tissues. In the plots, $15 \times 15 \mathrm{~cm}$ blocks of forest floor were removed about $0.5 \mathrm{~m}$ from each of the 9 soil sample sites. An inoculum block was placed horizontally in the center of the hole and covered with the removed forest floor. Rhizomorph production was measured from each inoculum block after 120 days. Inoculum blocks with rhizomorphs attached were placed in plastic bags and returned to the laboratory where the length of rhizomorphs produced by each stem section was measured. The survival of Armillaria in these blocks was then assessed by placing the sections (sans rhizomorphs if any) in a moist potting mix in plastic bags in the dark, and recording rhizomorph production after 90 days incubation at about $22^{\circ} \mathrm{C}$.

\section{Determination of Armillaria species}

Isolations from rhizomorphs collected in the soil blocks sampled in November 1995 were attempted for each sample in which rhizomorphs occurred. Rhizomorphs were washed under running water, cut into $1-2 \mathrm{~cm}$ sections, and soaked and shaken in 3 successive solutions of $1 \%$ Tween 80 (1-2 $\mathrm{min}$ ), $0.5 \%$ sodium hypochlorite (2 min), and $95 \%$ ethanol $(1 \mathrm{~min})$. They were then plated on BDS selective agar $(15 \mathrm{~g}$ malt, $4 \mathrm{mg}$ of $50 \%$ benomyl, $2 \mathrm{mg}$ dichloran, $100 \mathrm{mg}$ streptomycin, and $15 \mathrm{~g}$ agar in $1 \mathrm{I}$ water) (Worrall 1996). 
Isolates from the same plot were paired together in all possible combinations on malt plus agar ( $30 \mathrm{~g}$ malt, $10 \mathrm{~g}$ proteose peptone, $30 \mathrm{~g}$ glucose and $15 \mathrm{~g}$ agar in $1 \mathrm{I}$ water) in order to determine the somatic incompatibility groups (SIG) present on the plot (Adams 1974, Rayner et al. 1984). Then, using a method developed by McDonald et al. (1998 and personal communication with G.I. McDonald), the species of each SIG was determined by diploid-diploid pairings on malt plus agar with diploid tester isolates of A. calvescens, A. gallica, A. gemina Bérubé and Dessureault, A. mellea and A. sinapina Bérubé and Dessureault. If a black line formed on $90 \%$ or more of the pairings (18 per each unknown SIG, 6 tester strains $\times$ unknown $\times 3$ replicates) between the unknown and the tester strains for a given species, then the unknown was considered a different species. If the black line formed in less than $50 \%$ of the pairings, then the unknown isolate was considered to be the same species as the tester strain. Tester isolates were provided by G.I. McDonald, USFS, Moscow, ID, T. Harrington, ISU, Ames, lowa, and J. Anderson, Univ. Toronto, Canada.

\section{Statistical analysis}

For the present study, we were primarily concerned with the influence of liming on the Armillaria inoculum. However, as the application of herbicide and the fencing dramatically changed the understory present, we took those treatments into account in the analysis to rule out any possible bias. Preliminary analysis indicated that fencing had no influence on the abundance and vigor of Armillaria rhizomorphs and this treatment was dropped from subsequent analyses.

Statistical analyses were performed using SAS Inc software (SAS Inc, 1990). Categorial data were analyzed by generalized linear modeling with the GENMOD procedure. We assumed a binomial distribution of the data and used the logistic link function. The model validity was checked using the deviance/degree of freedom ratio, by plotting deviance residuals against the linear predictor and with half-normal plot (Collett, 1991). Grouped binary data were used for analyzing frequency of food bases colonization by Armillaria and frequency of rhizomorphs production from buried colonized wood sections. Ungrouped binary data were used for analyzing the other categorial data because one of the effects introduced in the model, the distance to the nearest colonized food base, had a different value for each data.

Length of rhizomorphs in the soil samples with rhizomorphs present and rating of ectotrophic rhizomorphs abundance on tree root collars were analyzed by variance analysis using SAS procedure GLM (SAS Inc, 1990). Data were log-transformed to have normally distributed residuals when appropriate. Herbicide application and liming were introduced as fixed effects and block as a random effect. A plot effect, nested within the bloc, herbicide, and liming effect was introduced. Fisher tests were computed using the plot mean square instead of the error mean square as denominator for all effects except for liming and herbicide. For those 2 effects, the liming $x$ block and herbicide $\mathrm{x}$ block mean square were used as denominators respectively.

A principal component analysis was conducted using SAS procedure PRINCOMP (SAS Inc, 1990) to study the relationship among the different measures of rhizomorphs 
abundance and vigor. The individuals were the 32 plots.

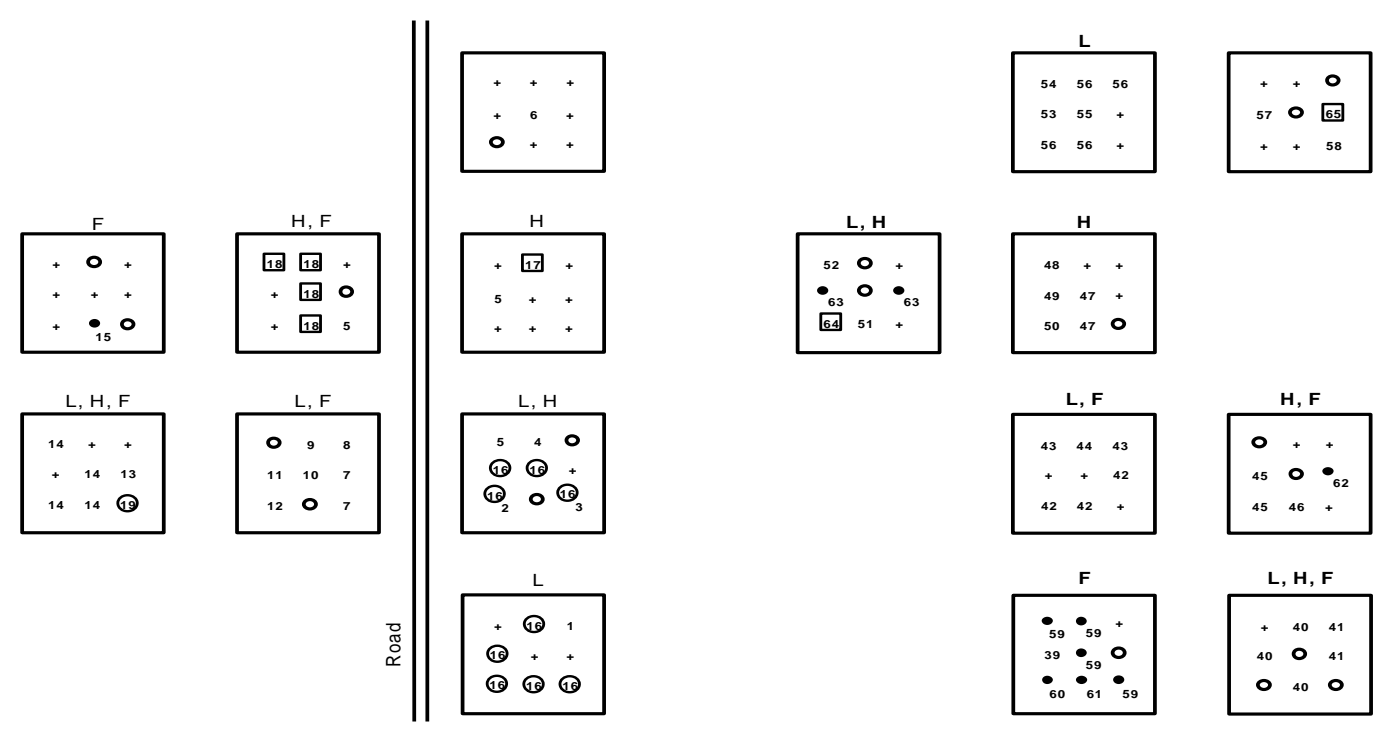

Black Diam ond, block 1

Cherry Springs, block 3
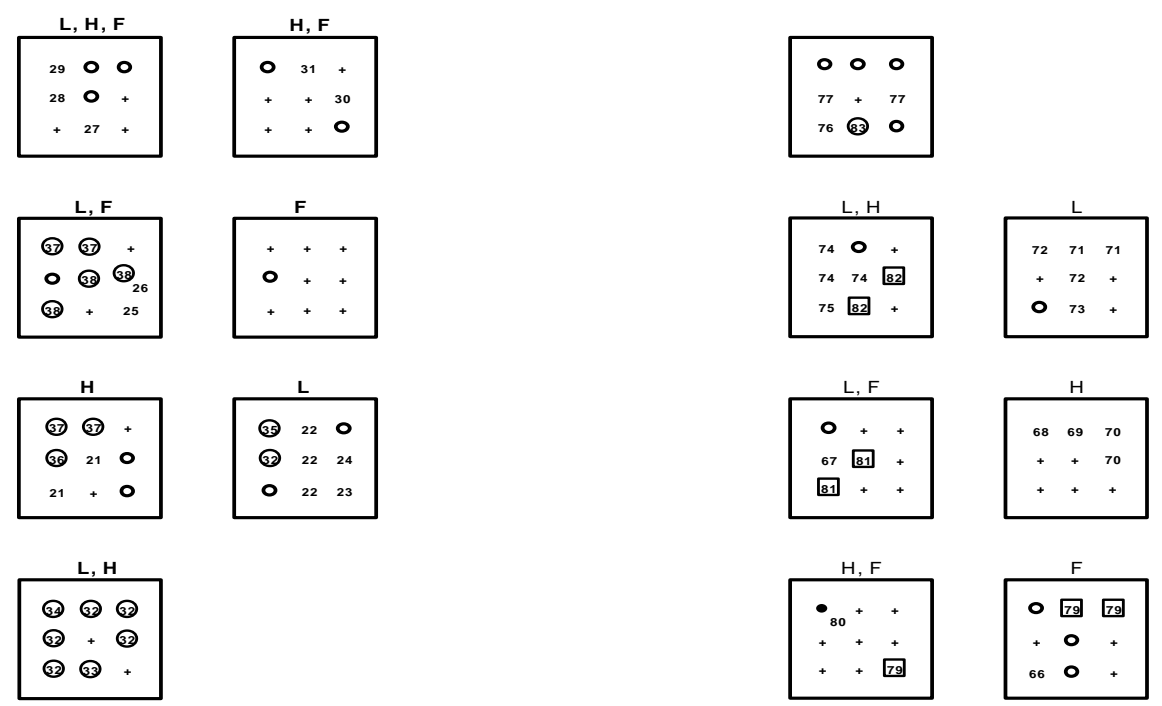

$$
\begin{array}{|ccc|}
\hline+ & + & 0 \\
+ & 20 & 20 \\
+ & 0 & + \\
\hline
\end{array}
$$

Black Diam ond, block 2

Cherry Springs, block 4

Fig. 1. Distribution of Armillaria species present as rhizomorphs in soil blocks sampled in November 1995. +, no rhizomorphs in the sample; O, no isolate obtained; 1 , A. calvescens; (1), A. mellea; 1 , A. gemina; $\bullet$, not identified. Numbers indicate the vegetative incompatibility groups. L, limed; H, herbicided; F, fenced. 


\section{Results}

\section{Armillaria species present}

One hundred and forty six isolates of Armillaria were recovered from the rhizomorphs present in the soil blocks sampled. Three putative species were found on the plots, A. calvescens, A. mellea and A. gemina. A fourth group of isolates was present but was not identified to species. A. calvescens, was isolated from 28 of the 32 plots $(66.3 \%$ of the isolates) while A. mellea and A. gemina $(19.2 \%$ and $10.3 \%$ of the isolates respectively) were isolated each from 8 and 9 plots respectively (Fig. 1a,b,c,d). A. mellea was present only in Black Diamond blocks 1 and 2 (Fig. 1a and b). About 8 percent of the isolates could not be identified to species. About 70 percent of the soil blocks from which $A$. calvescens was isolated came from the limed plots while 86 percent of the $A$. mellea and 40 percent of the $A$. gemina isolates came from limed plot soil samples. The genets of $A$. calvescens were generally of small size: about 41 percent of the soil samples yielding an isolate of $A$. calvescens, yielded an SIG that was present only in that soil sample. SIG's of A. gemina and A. mellea were slightly larger: only 20 percent of the soil samples yielding an isolates of one of these two species yielded an SIG that was present only in that soil sample (Fig. 1a, b, c and d).

Table 2. Relationship between the frequency of food bases colonization by Armillaria and of soil samples with rhizomorphs present to treatment variables: component likelihood $\chi^{2}$ values associated with the introduction of each effect into the generalized linear model

\begin{tabular}{lcrrr}
\hline Effect & Df & $\begin{array}{c}\text { \% food bases } \\
\text { colonized }\end{array}$ & $\begin{array}{c}\text { \% soil samples } \\
\text { with rhizomorphs }\end{array}$ & $\begin{array}{c}\text { \% soil samples } \\
\text { with rhizomorphs } \\
\text { of } A \text {. calvescens }{ }^{\text {a }}\end{array}$ \\
\hline $\begin{array}{l}\text { Distance to nearest food base } \\
\text { \% Sugar Maple c }\end{array}$ & 1 & - & $17.40(0.000)^{\mathrm{b}}$ & $10.16(0.001)$ \\
Block & 1 & $91.70(0.000)$ & $11.83(0.001)$ & $7.24(0.007)$ \\
Liming & 3 & $2.99(0.393)$ & $5.98(0.113)$ & $2.20(0.532)$ \\
Herbicide & 1 & $88.51(0.000)$ & $9.75(0.002)$ & $6.54(0.011)$ \\
\% Sugar Maple x Liming & 1 & $3.23(0.073)$ & $0.11(0.742)$ & $1.92(0.166)$ \\
Block x Liming & 1 & $5.24(0.022)$ & $2.38(0.123)$ & $2.35(0.125)$ \\
Block x Herbicide & 3 & $2.17(0.538)$ & $5.87(0.118)$ & $3.01(0.390)$ \\
Liming x Herbicide & 3 & $16.18(0.001)$ & $0.47(0.926)$ & $4.40(0.222)$ \\
& 1 & $0.17(0.679)$ & $0.31(0.577)$ & $2.88(0.090)$ \\
Deviance d & 17 & $19.77(0.286)$ & & - \\
\hline
\end{tabular}

a Only soil samples from which an isolate determined as A. calvescens was obtained were used as data.

${ }^{\mathrm{b}}$ Likelihood $\chi^{2}$ value (probability associated with the $\chi^{2}$ value)

${ }^{\mathrm{C}}$ Proportion of the plot basal area in sugar maple.

d Model deviance is given just for the proportion of food bases colonized by Armillaria because it can only be interpreted for grouped binary data 


\section{Abundance of rhizomorphs in soil, on food bases, and on sugar maple root collars}

The proportion of soil blocks sampled that had rhizomorphs, as well as the proportion of potential food bases colonized by Armillaria was greatly enhanced by liming (Table 2 and Fig. 2). These two proportions were also higher in plots with a high percent of the basal area in sugar maple prior to when the stands were thinned. Liming increased the proportion of soil samples with rhizomorphs or of food bases colonized only in plots with a low percent of basal area in sugar maple (Fig. 2a, b). However, the percent basal area of sugar maple $x$ liming interaction was significant only for the proportion of potential food bases colonized, but not for the proportion of soil samples with rhizomorphs (Table 2). Herbicide application increased food bases colonization frequency in block 2, but had no influence in the other blocks (results not shown).
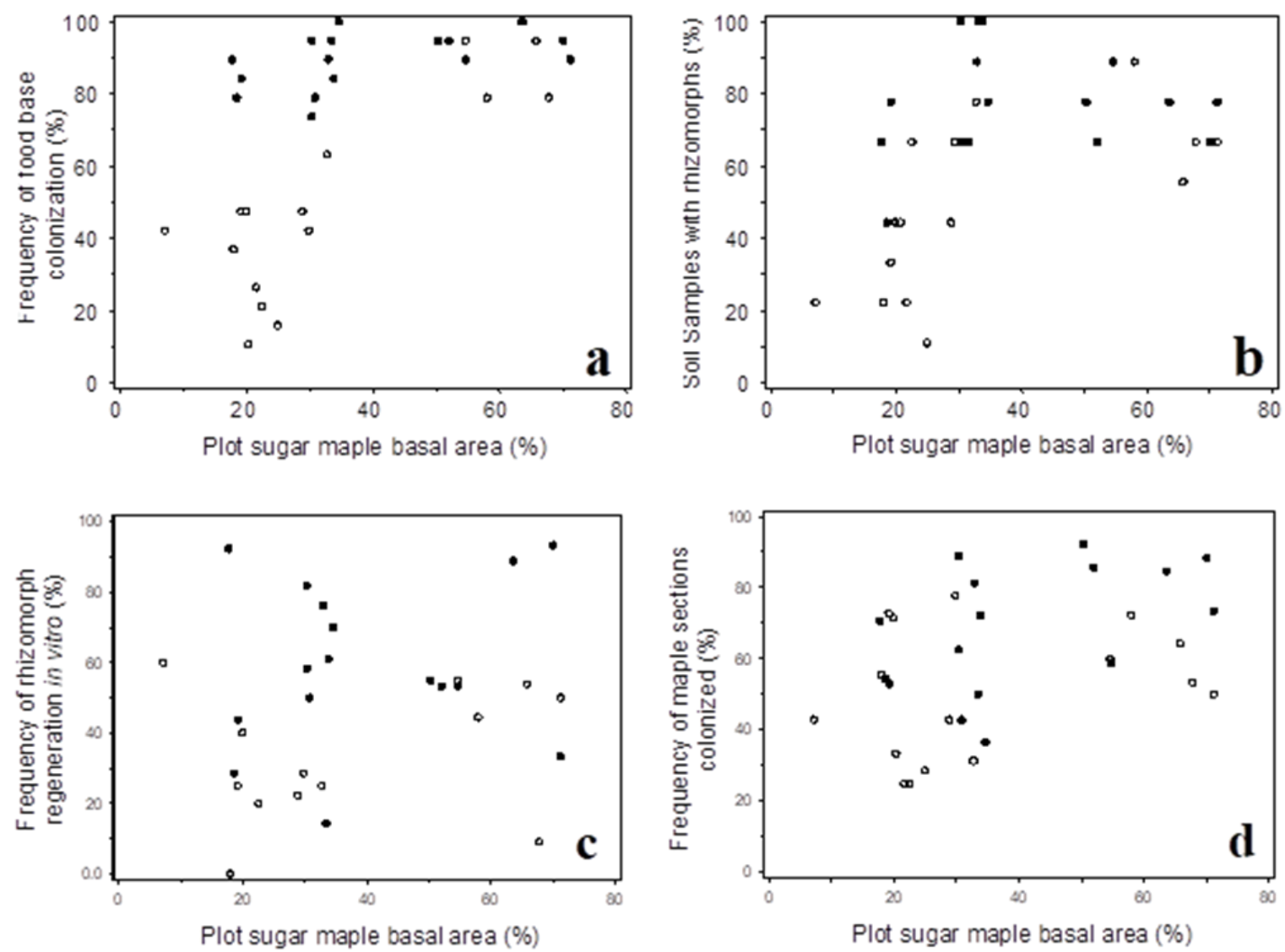

Fig 2. Relationship of Armillaria variables with plot sugar maple basal area and the effect of liming. Frequency of a) food base colonization (15); b) soil samples with rhizomorphs (9); c) rhizomorph regeneration on potato tubers in vitro (4-22); d) colonization of stripe maple stem sections in vivo (7-18); sample size is given between the parenthesis. ๑, Plots limed; $\circ$, Plots not limed. 
The probability of finding rhizomorphs in a soil sample was inversely related to the distance to the nearest colonized food base (Table 2). About 75 percent of the soil samples contained rhizomorphs when a food base was within $1 \mathrm{~m}$, but only 30 percent contained rhizomorphs when the nearest food base was more than $5 \mathrm{~m}$ away (Fig. 3a). When only data for soil samples with rhizomorphs from which $A$. calvescens had been isolated and identified were used, results were identical to those where all the soil samples with rhizomorphs were analyzed (Table 2). The abundance (length) of rhizomorphs per soil block, when rhizomorphs were present, was not influenced by liming or herbicide application (results not shown).

Table 3. Number of food bases of different tree species examined and frequency of colonization by Armillaria

\begin{tabular}{llccccc}
\hline & Beech & Birch & $\begin{array}{c}\text { Black } \\
\text { cherry }\end{array}$ & $\begin{array}{c}\text { Sugar } \\
\text { maple }\end{array}$ & $\begin{array}{c}\text { not } \\
\text { determined }\end{array}$ \\
\hline Plot not & No examined & 27 & 11 & 14 & 49 & 202 \\
Limed & \% colonized & 33 & 27 & 28 & 67 & 55 \\
\hline \multirow{2}{*}{ Plot limed } & No examined & 23 & 3 & 13 & 56 & 209 \\
& \% colonized & 83 & 100 & 77 & 96 & 89 \\
\hline
\end{tabular}

Food bases, mainly logs and stumps, were very abundant in all the plots: the median of the distance from a soil sample point to the nearest food base was $1.5 \pm 0.1 \mathrm{~m}$ and ranged from $1 \mathrm{~m}$ to $2 \mathrm{~m}$, depending on the plot. Frequency of food base colonization depended strongly on the tree species: food bases from sugar maple were colonized more often than those from beech (Fagus grandifolia Ehrh.), sweet birch (Betula lenta L), or black cherry (Prunus serotina Ehrh.) (Table 3). This was especially the case in unlimed plots. In limed plots, differences in frequency of food bases colonization among the different species were small. The difference in frequency of food base colonization was related to the proportion of basal area of sugar maple that was present when the plots were thinned; this affected the proportion of food bases (primarily stumps and logs) that was from sugar maple.

Ectotrophic rhizomorphs were found on the root collars of almost all sugar maple trees examined (98\%), even in plots in which rhizomorphs were difficult to find on food bases. Rhizomorphs were generally much more frequent on root collars than on the snags, stumps and logs. The abundance of rhizomorphs on root collars was significantly different among the plots. However, these differences were neither linked to the lime/herbicide application (Table 4) nor to the proportion of the basal area in sugar maple $(r=0.144, \mathrm{df}=31$, probability of 0.433$)$. 
Table 4. Impact of liming on the abundance of ectotrophic rhizomorphs on sugar root maple collars: analysis of variance.

\begin{tabular}{lcccc}
\hline Source & Df & Mean Square & F Value & P value \\
\hline Model & 31 & 1.722 & 3.12 & 0.0001 \\
Error & 126 & 0.553 & & \\
Total & 157 & & & \\
\hline Block & 3 & 0.802 & 0.47 & 0.710 \\
Herbicide & 1 & 0.631 & 0.41 & 0.529 \\
Block x Herbicide & 3 & 1.532 & 0.89 & 0.465 \\
Liming & 1 & 3.958 & 2.32 & 0.225 \\
Block x Liming & 3 & 1.709 & 0.99 & 0.418 \\
Liming x Herbicide & 1 & 3.842 & 2.23 & 0.152 \\
Plot (Block x Liming x Herbicide) & 19 & 1.724 & 3.12 & 0.0001 \\
\hline
\end{tabular}

\section{Vigor of rhizomorphs}

When potato tubers were challenged for one month with rhizomorphs in laboratory conditions, rhizomorph pieces often produced new rhizomorphs (52\% of the 397 cases). However, they were able to colonize the tuber in just few cases. By contrast, when striped maple sections were challenged for 2 months with rhizomorphs in situ in the forest soil, intact rhizomorphs frequently produced new rhizomorphs and colonized the sections ( $70 \%$ and $63 \%$ of 430 cases respectively). There was no influence of liming or herbicide on the amount of new rhizomorphs formed by the rhizomorphs pieces that regenerated in laboratory conditions (results not shown).

Table 5. Factors affecting the ability of rhizomorph sections or intact rhizomorphs to regenerate and colonize substrates: component likelihood $\chi^{2}$ values associated with the introduction of each effect into the generalized linear model

\begin{tabular}{lccr}
\hline Effect & Df $\begin{array}{c}\text { \% Rhizomorphs sections } \\
\text { regenerating onto potatoes } \\
\text { in the laboratory }\end{array}$ & $\begin{array}{c}\text { \% Maple stem sections } \\
\text { colonized by Armillaria } \\
\text { in the forest floor }\end{array}$ \\
\hline Distance to nearest food base & 1 & $0.17(0.684)$ & $16.48(0.000)$ \\
\% Sugar Maple & b & $1.70(0.193)$ & $10.12(0.002)$ \\
Block & 1 & $12.24(0.007)$ & $13.73(0.003)$ \\
Liming & 3 & $27.07(0.000)$ & $6.66(0.010)$ \\
Herbicide & 1 & $4.15(0.042)$ & $0.80(0.371)$ \\
\% Sugar Maple x Liming & 1 & $0.06(0.811)$ & $2.82(0.093)$ \\
Block x Liming & 1 & $16.24(0.001)$ & $2.38(0.497)$ \\
Block x Herbicide & 3 & $15.32(0.002)$ & $6.69(0.082)$ \\
Liming x Herbicide & 3 & $3.40(0.065)$ & $2.28(0.131)$ \\
\hline
\end{tabular}

\footnotetext{
a Proportion of the plot basal area in sugar maple.

${ }^{\mathrm{b}}$ Likelihood $\chi^{2}$ value (probability associated with the $\chi^{2}$ value)
} 


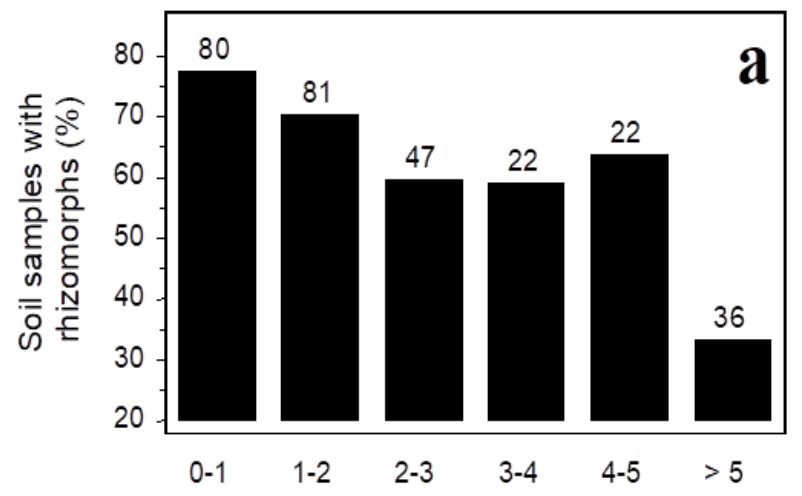

Distance to the nearest food base $(\mathrm{m})$

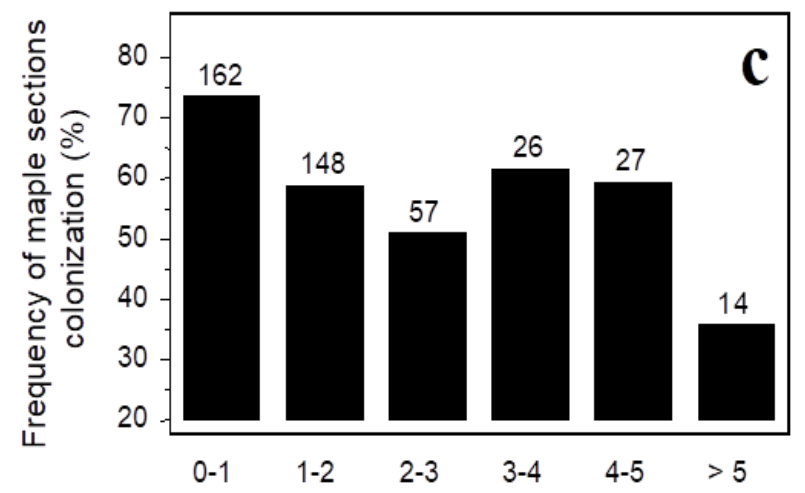

Distance to the nearest food base $(\mathrm{m})$

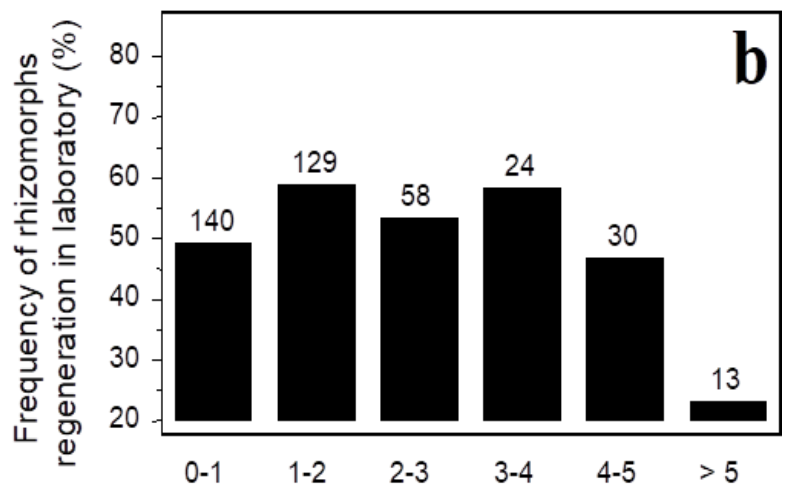

Distance to the nearest food base $(\mathrm{m})$

Fig 3. Relationship of Armillaria variables with distance to a colonized food base. Frequency of a) soil samples with rhizomorphs; b) rhizomorphs pieces that regenerated on potato tubers in the laboratory; c) stripe maple stem sections colonized by Armillaria in the forest floor. Sample size is given above the bars.

Liming significantly increased the likelihood of rhizomorph pieces to regenerate when inoculated onto potatoes in the laboratory (unlimed plots-35\%, limed plots$62.5 \%)$ and the likelihood of the stem sections to be colonized when attached to rhizomorphs in the forest soil (unlimed plots-54 \%, limed plots-69.5\%; Table 5, Fig. 2). However, the effect of liming on regeneration of rhizomorph pieces in the laboratory was not the same for all the blocks (Table 5). The likelihood of rhizomorph regeneration was greatly increased by liming in blocks 1,2 and 3, but in block 4, regeneration was about 40 percent with or without lime. In block 3 , regeneration frequency in laboratory conditions was lower for rhizomorph pieces from plots that received an herbicide application (38\%) compared to those that did not $(73 \%)$, but there was no influence of herbicide application in the other blocks (results not shown). The proportion of striped maple stem sections colonized in situ by Armillaria was higher in plots where a high proportion of the initial basal area was in sugar maple. However, basal area of sugar maple had no effect on the proportion of rhizomorph pieces that regenerated in 
laboratory conditions (Table 5 and Fig. 2c). Also, stem sections were more likely to be colonized by Armillaria if they were attached to a rhizomorph close to a food base (Table 5 and Fig. 3c); 70 percent of the stem sections attached to a rhizomorph within $1 \mathrm{~m}$ of a food base were colonized while just 28 percent of the sections were colonized where the food base was more than $5 \mathrm{~m}$ away. Likelihood of a rhizomorph piece to regenerate in laboratory conditions was not influenced by the distance of the soil sample from which it came to the nearest food base (Table 5 and Fig. 3b).

Table 6. Principal component analysis on the different measures of the abundance and vigor of Armillaria rhizomorphs per plot: matrix of correlation between the variables and correlation of the variables with the 2 first components of the analysis

\begin{tabular}{|c|c|c|c|c|c|}
\hline & $\begin{array}{l}\text { Soil samples } \\
\text { with rhizomorphs } \\
(\%)^{a}\end{array}$ & $\begin{array}{l}\text { Frequency of } \\
\text { food bases } \\
\text { colonization (\%) }\end{array}$ & $\begin{array}{l}\text { Abundance } \\
\text { at } \\
\text { root collar }\end{array}$ & $\begin{array}{l}\text { Frequency of } \\
\text { regeneration } \\
\text { in vitro (\%) }\end{array}$ & $\begin{array}{l}\text { Frequency of } \\
\text { maple sections } \\
\text { colonized (\%) }\end{array}$ \\
\hline $\begin{array}{l}\text { Soil samples with } \\
\text { rhizomorphs }\end{array}$ & 1.000 & & & & \\
\hline $\begin{array}{l}\text { Frequency of food } \\
\text { bases colonization }\end{array}$ & $\begin{array}{c}0.694 \\
(0.0001)^{\dagger}\end{array}$ & 1.000 & & & \\
\hline $\begin{array}{l}\text { Abundance at } \\
\text { root collar }\end{array}$ & $\begin{array}{c}0.428 \\
(0.016)\end{array}$ & $\begin{array}{c}0.393 \\
(0.029)\end{array}$ & 1.000 & & \\
\hline $\begin{array}{l}\text { Frequency of } \\
\text { regeneration in vitro }\end{array}$ & $\begin{array}{c}0.473 \\
(0.007)\end{array}$ & $\begin{array}{c}0.697 \\
(0.0001)\end{array}$ & $\begin{array}{c}0.288 \\
(0.116)\end{array}$ & 1.000 & \\
\hline $\begin{array}{l}\text { Frequency of maple } \\
\text { sections colonized }\end{array}$ & $\begin{array}{c}0.373 \\
(0.039)\end{array}$ & $\begin{array}{l}0.605 \\
(0.00013\end{array}$ & $\begin{array}{c}0.251 \\
(0.173)\end{array}$ & $\begin{array}{c}0.616 \\
(0.0002)\end{array}$ & 1.000 \\
\hline Component 1 & $\begin{array}{l}0.778 \\
(0.0001)\end{array}$ & $\begin{array}{l}0.904 \\
(0.0001)\end{array}$ & $\begin{array}{c}0.563 \\
(0.001)\end{array}$ & $\begin{array}{c}0.821 \\
(0.0001)\end{array}$ & $\begin{array}{c}0.751 \\
(0.0001)\end{array}$ \\
\hline Component 2 & $\begin{array}{c}0.282 \\
(0.124)\end{array}$ & $\begin{array}{l}-0.059 \\
(0.750)\end{array}$ & $\begin{array}{c}0.715 \\
(0.0001)\end{array}$ & $\begin{array}{l}-0.313 \\
(0.087)\end{array}$ & $\begin{array}{l}-0.415 \\
(0.020)\end{array}$ \\
\hline
\end{tabular}

\footnotetext{
${ }^{\text {a }}$ Assessment in November 1995 (9 soils samples per plot)

${ }^{\mathrm{b}}$ Based on15 food bases per plot

${ }^{c}$ Abundance of ectotrophic rhizomorphs on the root collar of sugar maple: mean tree rating per plot (4 trees per plot)

d Frequency of rhizomorph sections regeneration when they are inoculated onto potato tubers in the laboratory (3-22 rhizomorph sections per plot)

${ }^{\mathrm{e}}$ Frequency of maple stem sections left for 2 months attached to an intact rhizomorph in the forest floor that are colonized by Armillaria (7-18 maple sections per plot).

${ }^{f}$ Pearson coefficient of correlation (probability)
}

\section{Relationship between the measurements of rhizomorph abundance and vigor}

To study the relationship between abundance of food bases and abundance of rhizomorphs in soil and on tree root collars, a principal components analysis was conducted on the five measures of rhizomorph abundance and vigor.

The first axis of this principal component analysis accounted for 59.5 percent of the variability. Each of the 5 variables measuring the abundance and vigor of Armillaria 
rhizomorphs in the plots were significantly linked to this axis (Table 6. However, the correlation coefficient of the mean root collar ectotrophic rhizomorph rating per plot with the first axis was quite low, at 0.563 . The second axis of the principal component analysis accounted for 17.3 percent of the variability. Only the mean root collar ectotrophic rhizomorph rating per plot and to a lesser extent, percent of maple stem section colonized by Armillaria, were significantly correlated to this axis. The position of the 32 plots on the two axes of the principal component analysis is shown in Figure 4. Plots not limed or those with less than 50 percent of the initial basal area in sugar maple have negative values for axis 1, while those that were limed and/or had more than 50 percent of the basal area in sugar maple have positive values for axis 1 .

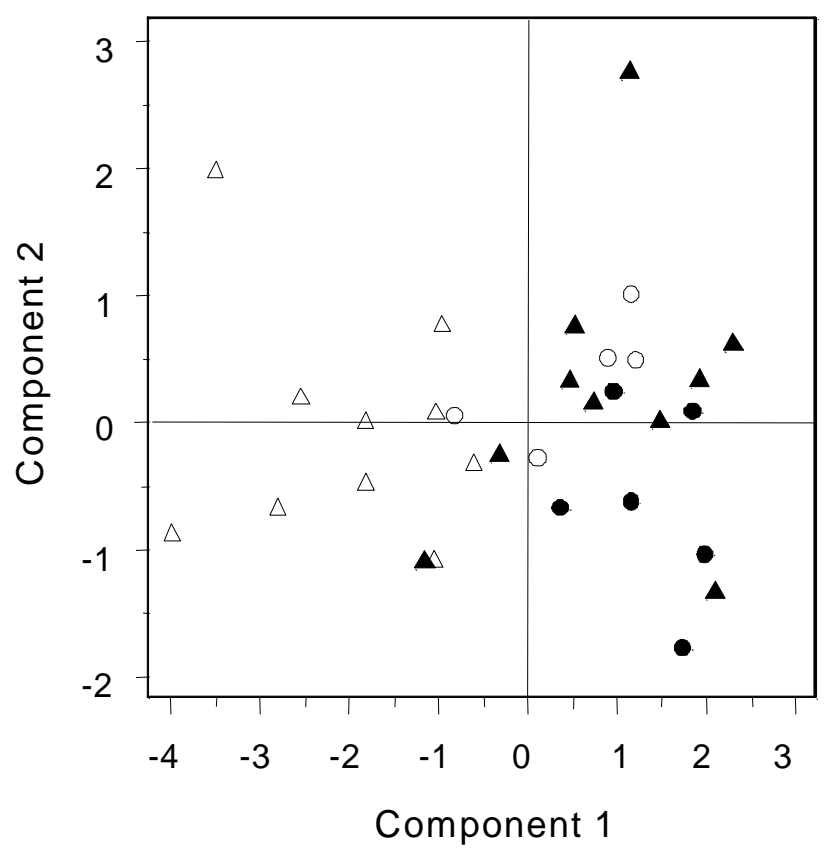

Fig 4. Position of the plots on the first plane of the principal component analysis on the Armillaria variables (mean abundance of rhizomorphs on sugar maple root collar per plot, frequency per plot of food base colonization, of soil samples with rhizomorphs, of rhizomorph regeneration on potato tubers in vitro and of colonization of stripe maple stem sections in vivo). $\triangle$, plots not limed; $\bigcirc$, plots limed; Filled symbol are for plots with more than $50 \%$ of the basal area in sugar maple and empty ones are for plots with less than $50 \%$ of the basal area in sugar maple. Of the total variation, $60 \%$ was in component 1 and $17 \%$ in component 2 .

\section{Production of rhizomorphs from colonized maple stem sections}

Altogether, just 17.9 percent of the artificially colonized stem sections produced rhizomorphs after 4 months incubation in situ in the plots. However, survival of Armillaria in the sections was high: 81.8 percent of the sections produced rhizomorphs after an additional incubation period of 3 months in laboratory conditions. Fewer sections colonized by the $A$. mellea isolate produced rhizomorphs in the plots, compared to the A. calvescens isolate (Table 7, Fig. 5) Also, the proportion of sections that produced 
rhizomorphs was higher in limed plots than in unlimed plots for both isolates (Fig. 5). Production of rhizomorphs from the sections was twice more frequent in block 1 and 2 than in block 3 and 4 regardless of treatment. The length of rhizomorphs produced by the sections that produced rhizomorphs was higher for the A. calvescens isolate $(12.4 \pm 3.7 \mathrm{~cm})$ than for the $A$. mellea isolate $(4.7 \pm 1.6 \mathrm{~cm})$. Rhizomorph growth in limed plots was higher $(11.6 \pm 3.5 \mathrm{~cm})$ than in unlimed plots $(6.3 \pm 3.6 \mathrm{~cm})$, but these differences were not statistically significant (results not shown).

Table 7. Proportion of artificially inoculated maple stem sections that produce rhizomorphs after an incubation of 4 months in the forest floor: component likelihood $\chi^{2}$ values associated with the introduction of each effect into the generalized linear model

\begin{tabular}{lll}
\hline Effect & Df & $\chi^{2}$ values \\
\hline Isolate $^{\mathrm{a}}$ & 1 & $28.38(0.000)^{\mathrm{b}}$ \\
Block $_{\text {Liming }}^{\mathrm{b}}$ & 3 & $24.53(0.000)$ \\
Isolate x Liming & 1 & $40.07(0.000)$ \\
Block x Liming & 1 & $2.11(0.549)$ \\
Block x Isolate & 3 & $1.96(0.581)$ \\
Deviance & 3 & $0.31(0.575)$ \\
\hline
\end{tabular}

a Two isolates, $A$. calvescens and A. mellea.

${ }^{\mathrm{b}}$ Likelihood $\chi^{2}$ value (probability associated with the $\chi^{2}$ value).

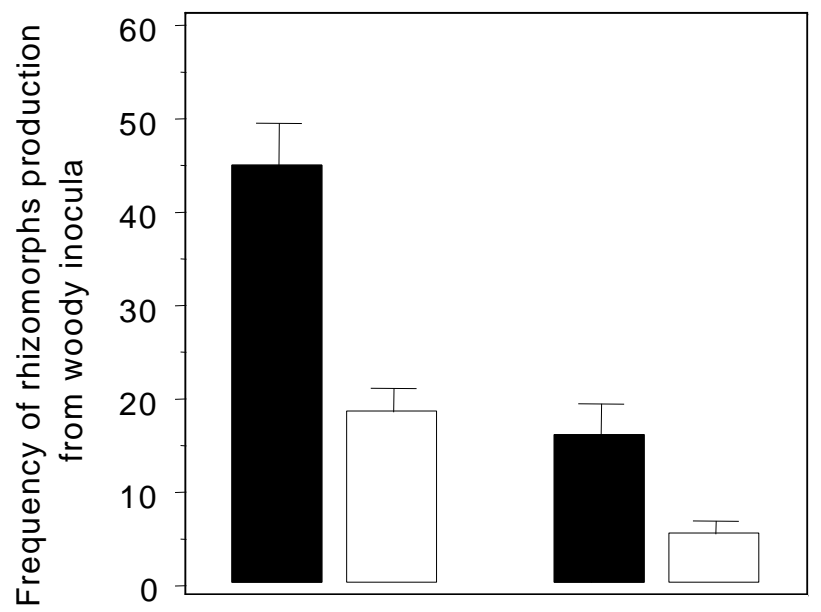

A. calvescens A. mellea

Fig 5. Frequency of rhizomorphs production by two Armillaria species from artificially colonized maple stem segments after an incubation of 4 months in the forest floor. Frequencies are computed from data pooled for plots limed ( $\square$ ) or unlimed $(\square)$. The standard error of the frequency is represented. 
Marçais et Wargo, 16

\section{Discussion}

The Armillaria species predominant in the plots was $A$. calvescens and it is very likely that most of the results presented here concern mainly that species. Indeed, concerning frequency of rhizomorphs in soil, frequency of food base colonization, frequency of rhizomorph sections regeneration in vitro and frequency of maple stem section colonization in situ, we reached similar conclusions than with all the data when sub-analysis were run only on data from grid points from which $A$. calvescens was obtained (only results concerning frequency of rhizomorphs in soil are shown). It was not possible to run a sub-analysis of rhizomorphs abundance on sugar maple root collar on data concerning $A$. calvescens because Armillaria species present on the collar were not identified and the trees location was not mapped. Also, wood segments artificially contaminated with $A$. calvescens were more likely to produce rhizomorphs when they were buried in the limed plots compared to the unlimed plots. A. calvescens acts primarily as a secondary parasite able to attack and kill only weakened hosts or as a butt rot organism (Blodgett and Worrall 1992a, Morrison, 1989). The higher abundance of $A$. calvescens in plots with a high proportion of sugar maple in the overstory corresponds to what is known from the literature, as this species has been reported to be more closely associated with maples (Bérubé and Dessureault, 1989, Blodgett and Worral, 1992a and 1992b). A. mellea was also commonly isolated from rhizomorphs in those plots, which is quite surprising because this species is not reported as a prolific rhizomorph producing Armillaria (Guillaumin et al, 1993). Indeed, the wood segments artificially colonized with $A$. mellea produced rhizomorphs far less frequently than those colonized by $A$. calvescens. Also production of rhizomorphs by $A$. mellea was enhanced in limed plots and this species was isolated mainly from the limed plots. Enhanced rhizomorphs production by $A$. mellea in soil with a $\mathrm{pH}$ over 7 have already been reported (Guillaumin, 1986) and Rishbeth (1982) reported that A. mellea killed trees predominantly on alkaline soils.

Our results clearly show that the abundance and vigor of Armillaria rhizomorphs in the plots were controlled by a combination of the soil base saturation and the initial proportion of sugar maple in the overstory. Wherever lime had been applied, raising the soil pH from about 4 to 6.5 (Long et al, 1997), or where sugar maple initially dominated the overstory, frequency of rhizomorphs in soil, frequency of food bases colonization and ability of rhizomorphs to colonize fresh maple sections were high. The basal area (BA) of sugar maple prior to thinning was more highly correlated with abundance and vigor of Armillaria rhizomorphs than either BA of sugar maple cut during the thinning or total basal area cut. A large proportion of the food bases was provided by the thinning. However, all of the plots experienced decline and mortality of sugar maple thus providing even more food bases. So, the BA of sugar maple prior to the thinning probably represented the total amount of food base from sugar maple present in these plots.

The selective logging done when the plots were established in 1985 (50\% of the basal area removed) created an abundance of suitable food bases in all the plots and 
probably led to a buildup of the Armillaria population. The genets of $A$. calvescens, the most abundant species, were of a small size: many of the genets were present in only one soil sample. The genets were most likely recent, probably created after the disturbance by the logging.

Colonization frequency of sugar maple food base was high in all plots and the lime application increased the colonization frequency of food bases of beech, birch, and black cherry. This probably explains why liming increased food base colonization frequency only in plots with a low proportion of the BA in sugar maple. The 10-year delay between the establishment of plots and our study was long enough for the food bases to be colonized by Armillaria and for the buildup of the rhizomorph population in the soil (Pronos and Patton, 1977; Stanosz and Patton, 1991). Thus, the greater abundance of food bases in plots limed and/or dominated by sugar maples explains partially the greater frequency of rhizomorphs in the soil, and their increased ability to regenerate in laboratory conditions or to colonize maple stakes in situ in the forest floor. Indeed, frequency of the rhizomorphs, as well as their ability to regenerate in vitro or colonize a substrate in situ, were greater close to the food bases.

Liming apparently influenced the abundance of rhizomorphs in the soil in ways other than by increasing food base availability. Liming also increased the production of rhizomorphs from artificially colonized wood sections buried in the plots suggesting a chemical or $\mathrm{pH}$ effect. Soil $\mathrm{pH}$ has already been found to affect the production of rhizomorphs of other Armillaria species: production of rhizomorphs in alkaline soil was either favored or unaffected for A. gallica (Morrison, 1974; Rishbeth, 1985; Guillaumin, 1986).

By contrast, the higher frequency of colonized food bases and of rhizomorphs in the soil in plots limed or dominated by sugar maple was not linked to a higher abundance of ectotrophic rhizomorphs on the root collar of living sugar maple trees. In the principal component analysis, abundance of ectotrophic rhizomorphs on the root collar was not strongly linked to the other measures of rhizomorphs abundance and vigor. One possibility is that ectotrophic colonization of the root collar is the last phase in a population buildup for secondary parasites like A. calvescens, occurring only after the colonization of the food bases and the increase of rhizomorph abundance in the soil. The span of 10 years was perhaps not long enough to complete the buildup. Another possibility is that once a root collar is colonized by rhizomorphs, they become independent of the original food base and derive nutrients from the colonized living tree.

The lime application improved the crown appearance and the growth of the sugar maples, but not of the beech trees and black cherries (Long et al, 1997). Thus, health of sugar maple was improved in the plots in which the buildup of Armillaria inoculum also was higher. Probably, liming increased the vigor of the maple trees and enabled them to resist a secondary pathogen such as $A$. calvescens. The deterioration of the crown of sugar maple, beech and black cherry in all the plots from 1989 to 1993, due to defoliation by insects, mainly the elm spanworm (Ennomos subsignarius Hubner) was not enough apparently to weaken all trees to the point they became susceptible to the Armillaria sp. present, although some trees did die during this period. A post-mortality 
Marçais et Wargo, 18

assessment indicated that Armillaria had colonized most of these recently killed trees. The abundance of ectotrophic rhizomorphs on the root collars was not increased by the lime application, and it is possible that the inoculum potential which challenged the sugar maples had not really changed despite the increase in the number of food bases available and of rhizomorph frequency in the soil.

\section{Acknowledgement}

We want to thank the P. R. Lilja, from the Pennsylvania Bureau of Forestry and S. B. Horsley, from the USDA forest service that allowed us to work on the experimental plots and to all people that took care in installing and maintaining it. C. Fagan was of a great help for the technical work as were G. S. Walton and C. Chabanet for the statistical analysis.

\section{Reference}

Adams, D. H. 1974. Identification of clones of Armillaria mellea in young-growth ponderosa pine. Northwest Science 48:21-28.

Auchmoody, L. R. 1985. Effect of lime, fencing, and herbicides on establishment and growth of regeneration on problem sites. Study Plan 4110-FS-NE-1152-141. NEFES Warren Penna.

Bérubé, J. A., and Dessureault M. 1989. Morphological studies of the Armillaria mellea complex: two new species, A. gemina and A. calvescens. Mycologia 81:216-225

Blodgett, J. T., and Worrall, J. J. 1992a. Distributions and hosts of Armillaria species in New York. Plant Disease. 76:166-169

Blodgett, J. T., and Worrall, J. J. 1992b. Site relationships of Armillaria species in New York. Plant Disease. 76:170-174

Collett, D., 1991. Modeling Binary data. Ed. Chapman \& Hal. $369 \mathrm{p}$

Garrett, S. D., 1956. Rhizomorph behaviour in Armillaria mellea (Vahyl) Quél. II. Logistic of infection. Annals of Botany, 20:193-209

Gregory, S. C. 1984. The use of potato tubers in pathogenicity studies of Armillaria species. Pages 148-160, in: Kile, G. A., Ed. Proceedings of the 6Th international conference on root and but rots of forest trees, 1983, Melbourne, Victoria and Gympie, Queensland, Australia. Melbourne, IUFRO.

Guillaumin, J. J. 1986. Contribution à l'étude des armillaires phytopathogènes, en particulier du groupe mellea : cycle caryologique, notion d'espèce, rôle biologique des espèces. Thèse de l'Université de Lyon I. page 177-186

Guillaumin, J. J., Mohammed, C., Anselmi, N., Courtecuisse, R., Gregory, S. C., Holdenrieder, O., Intini, M., Lung, B., Marxmüller, H., Morrison, D., Rishbeth, J., Termorshuizen, A. J., Tirro, A. and Van Dam, B. 1993. Geographical distribution and ecology of the Armillaria species in western Europe. Eur. J. For. Path., 23:321-341

Houston, D. R., and Kuntz, J. E. 1964. Pathogen associated with Maple blight. In: Studies of Maple blight. Research Bulletin 250, University of Wisconsin, Madison

Kolb, T. E., and McCormick, L. H. 1993. Etiology of sugar maple decline in four Pennsylvania stands. Can. J. For. Res. 23:2395-2402.

Long, R. P., Horsley, S. B., and Lilja, P. R. 1997. Impact of forest liming on growth and crown vigor of sugar maple and associated hardwoods. Can. J. For. Res., 27:1560-1573 
Manion, P. D. 1991. Tree disease concepts. Prentice Hall, Englewood Cliffs, N.J.

McDonald, G. I., Klopfenstein, N. B., and Kim, M. S. 1998. Ecology of Armillaria in a 16-year-old northern Idaho white pine plantation. (Abstract). Phytopathology 88:560. Publ. No P-19980431AMA.

McWilliams, W. H., White, R., Arner, S. L., Nowak, C. A., and Stout, S. L. 1996. Characteristics of declining forest stands on the Allegheny National Forest. USDA For. Serv. Res. Note NE-360.

Morrison, D. J. 1974. Effect of pH on rhizomorph growth of Armillaria mellea. Bi-monthly Research Notes 30. Canadian Forestry Service: 18-19

Morrison, D. J. 1989. Pathogenicity of Armillaria species is related to rhizomorph growth habit. Pages 584-589, in: Morrison, D. J., ed. Proceedings of the 7th international conference on root and butt rots; 1988 August 9-16; Vernon and Victoria, B. D. Victoria, BC: International Union for Forestry Research Organizations.

Pronos, J., and Patton, R. F. 1977. Penetration and colonization of oak roots by Armillaria mellea in Wisconsin. Eur. J. For. Path, 8:259-267.

Rayner, A. D. M., Coates, C., Ainsworth, A. M. 1984. The biological consequences of the individualistic mycelium. Pages 510-540, in: Jennings, D. H.; Rayner, A. D. M., eds. The ecology and physiology of the fungal mycelium: Proceedings of the 4th symposium. British Mycological Society, Cambridge University Press.

Redfern, D. B., and Filip, G. M. 1991. Inoculum and Infection, Pages 48-60 in: Armillaria root disease. Shaw III, C. G. and Kile, G. A. Agriculture Handbook No. 691, Forest Service USDA, $233 \mathrm{pp}$.

Rishbeth, J. 1982. Species of Armillaria in southern England. Plant Pathology 31:9-17.

Rishbeth, J. 1985. Infection cycle of Armillaria and host response. Eur. J. For. Path. 15:332-341

Singh, P. 1981. Armillaria mellea: growth and distribution of rhizomorphs in the forest soils of Newfoundland. Eur. J. For. Path. 11:208-220.

Stanosz, G R., and Patton, R. F. 1991. Quantification of Armillaria rhizomorphs in Wisconsin aspen sucker stands. Eur. J. For. Path, 21:5-16

Twery, M. J., Mason, G. N., Wargo. P. M., and Gottschalk, K. W. 1990. Abundance and distribution of rhizomorphs of Armillaria spa. in defoliated mixed oak stands in western Maryland. Can. J. Bot. 20:674-678

Wargo, P. M. 1977. Armillariella mellea and Agrilus bilineatus and mortality of defoliated oak trees. Forest Science, 23:485-492

Wargo, P. M. 1984. How stress predisposes trees to attack by Armillaria mellea - a hypothesis. Pages 115-122, in: Kile, G. A., Ed. Proceedings of the 6Th international conference on root and but rots of forest trees, 1983, Melbourne, Victoria and Gympie, Queensland, Australia. Melbourne, IUFRO.

Wargo, P. M. 1987. Occurrence of rhizomorphs of Armillaria in soils from declining red spruce stands in three forest types. Plant Disease 71:163-167

Wargo, P. M., and Harrington, T. C. 1991. Host stress and Susceptibility. Pages 88-101 In: Armillaria root disease.; Shaw III, C. G. and Kile, G. A. Agriculture Handbook No. 691, Forest Service USDA, $233 \mathrm{pp}$. 